\title{
HUBUNGAN ANTARA PRASANGKA SOSIAL DAN INTENSI MELAKUKAN DISKRIMINASI MAHASISWA ETNIS JAWA TERHADAP MAHASISWA YANG BERASAL DARI NUSA TENGGARA TIMUR
}

\author{
Femita Adelina \\ Prodi Psikologi, Fakultas Pendidikan Psikologi, Universitas Negeri Malang \\ e-mail: femita.adelina26@gmail.com \\ Fattah Hanurawan \\ Prodi Psikologi, Fakultas Pendidikan Psikologi, Universitas Negeri Malang \\ Indah Yasminum Suhanti \\ Prodi Psikologi, Fakultas Pendidikan Psikologi, Universitas Negeri Malang
}

\begin{abstract}
Abstrak
Penelitian ini bertujuan untuk mengungkap hubungan antara prasangka sosial dan intensi melakukan diskriminasi mahasiswa etnis Jawa terhadap mahasiswa yang berasal dari Nusa Tenggara Timur. Rancangan penelitian yang digunakan adalah deskriptif dan korelasional. Sampel penelitian dipilih dengan purposive sampling. Berdasarkan analisis deskriptif diketahui bahwa prasangka sosial dan intensi melakukan diskriminasi berada dalam kategori sedang. Hasil penelitian menunjukkan bahwa ada hubungan yang positif dan signifikan antara prasangka sosial dan intensi melakukan diskriminasi mahasiswa etnis Jawa terhadap mahasiswa yang berasal dari Nusa Tenggara Timur.
\end{abstract}

Kata Kunci: prasangka sosial, intensi diskriminasi, mahasiswa Jawa.

Etnis Jawa merupakan etnis terbesar di Indonesia dengan jumlah 95,2 juta $(40,2 \%)$ dari seluruh penduduk Indonesia (Na'im dan Syaputra, 2010). Jumlah etnis Jawa yang sangat besar tersebut tersebar di seluruh wilayah Indonesia. Jawa Timur merupakan provinsi dengan jumlah etnis Jawa terbesar kedua. Etnis Jawa tersebar di seluruh wilayah kota dan kabupaten di Jawa Timur. Kota Malang merupakan salah satu kota di Jawa Timur yang mayoritas dihuni oleh etnis Jawa.

Sebagai kota pendidikan, Kota Malang tidak hanya dihuni oleh etnis Jawa saja, namun juga etnis-etnis lain di Indonesia salah satunya adalah etnis yang berasal dari Nusa Tenggara Timur. Mayoritas dari mereka merupakan mahasiswa dari perguruan tinggi yang tersebar di Kota Malang baik negeri maupun swasta. Sebagai kota yang menjadi tujuan mahasiswa dari berbagai daerah di Indonesia, sangat mungkin munculnya prasangka sosial di Kota Malang. Akhir-akhir ini sering terjadi konflik antar etnis di Kota Malang, di mana dari semua konflik antar etnis yang terjadi selalu melibatkan maha- siswa yang berasal dari Nusa Tenggara Timur. Sepanjang tahun 2014 hingga 2016 setidaknya telah terjadi empat kali kasus tawuran yang melibatkan mahasiswa asal Nusa Tenggara Timur.

Konflik antar warga Malang dan mahasiswa Nusa Tenggara Timur dikarenakan adanya diskriminasi yang dirasakan oleh mahasiswa Nusa Tenggara Timur. Salah satu contoh bentuk diskrimasi adalah Banyak kos di Kota Malang yang hanya menerima mahasiswa muslim, sementara mayoritas mahasiswa asal Nusa Tenggara Timur merupakan non muslim. Bentuk diskriminasi lainnya adalah harga kos yang dipatok jauh lebih tinggi dari harga normal. Dalam mengurangi potensi konflik tersebut, mahasiswa asal Nusa Tenggara Timur di Kota Malang menemui Wakil Walikota Malang untuk melakukan dialog terkait permasalahan tersebut (Terasntt.com, 2016). Hasil wawancara yang dilakukan peneliti terhadap dua orang mahasiswa yang berasal dari universitas negeri dan swasta di Kota Malang juga menujukkan bahwa terdapat prasangka dan intensi 
melakukan diskriminasi terhadap mahasiswa yang berasal dari Nusa Tenggara Timur.

Diskriminasi merupakan sebuah perilaku negatif, sementara prasangka sosial merupakan sikap negatif. Sikap menentukan terjadinya perilaku melalui variabel perantara yang disebut niat untuk melaksanakan perilaku (Hanurawan, 2010). Dari pernyataan itu terlihat bahwa sebagai sebuah sikap, prasangka sosial dapat menimbulkan perilaku diskriminasi karena terdapat intensi (niat) melakukan diskriminasi. Berdasarkan hal tersebut peneliti tertarik untuk mengungkap apakah ada hubungan antara prasangka sosial dan intensi melakukan diskriminasi mahasiswa etnis Jawa terhadap mahasiswa yang berasal dari Nusa Tenggara Timur.

\section{PRASANGKA SOSIAL}

Menurut Ahmadi (2007) prasangka sosial adalah suatu sikap negatif yang diperlihatkan oleh individu atau kelompok terhadap individu lain atau kelompok lain. Prasangka sosial merupakan evaluasi negatif atas suatu kelompok atau seseorang berdasarkan pada keanggotaan orang itu dalam suatu kelompok (Taylor dkk., 2012). Bentuk prasangka sosial dikelompokkan menjadi dua yaitu prasangka terang-terangan dan prasangka halus. Prasangka terang-terangan dikenal sebagai prasangka gaya lama, sementara prasangka halus dikenal sebagai prasangka modern. Pettigrew dan Meertens (Brown, 2005) mengemukakan tentang pemilahan serupa bentuk dikotomi prasangka modern dan gaya lama ini. Mereka menyebutnya sebagai prasangka yang "subtle" (tidak terang-terangan/ halus/ tersembunyi) dan yang "blatant" (terangterangan). Terdapat perbedaan komponen yang menyusun subtle prejudice and blatant prejudice (De Caroli dkk., 2012). Subtle prejudice disusun oleh tiga komponen yaitu pertahanan nilai tradisional (the defence of traditional value), melebih-lebihkan perbedaan budaya (the exaggeration of cultural differences), dan penolakan emosi-emosi positif (the denial of positive emotions). Sementara blatant prejudice disusun oleh dua komponen yaitu ancaman dan penolakan terhadap outgroup (the threat and rejection of outgroup) dan anti-intimasi (the anty-intimacy).

Prasangka sosial dapat timbul karena terdapat faktor-faktor tertentu. Ada empat faktor utama penyebab timbulnya prasangka sosial (Baron dan Byrne dalam Hanurawan, 2010). Keempat faktor tersebut yaitu konflik antar kelompok secara langsung, pengalaman belajar di masa awal, kategori sosial, dan beberapa aspek dalam kognisi sosial. Prasangka sosial dapat timbul karena adanya kompetisi dalam mendapatkan kekuasaan atau sumber daya. Hal ini dijelaskan dalam teori konflik kelompok realistik (realistic group conflict theory). Teori ini menyatakan bahwa prasangka muncul karena terdapat kelompok-kelompok yang saling memperebutkan kekuasaan atau sumber daya yang jumlahnya terbatas. Faktor kedua yang dapat menyebabkan prasangka adalah pengalaman belajar pada masa awal perkembangan. Seseorang dapat berprasangka karena lingkungan atau kelompoknya telah mempersiapkannya untuk berprasangka. Hal ini dijelaskan dalam teori belajar sosial. Menurut teori ini, prasangka sosial merupakan sesuatu yang dipelajari sama halnya belajar nilai-nilai sosial yang lain. Faktor ketiga adalah adanya kategori sosial. Seseorang akan cenderung menyederhanakan lingkungannya dengan membuat kategori, yaitu dengan cara mengklasifikasikan objek atau manusia ke dalam kelompokkelompok. Hal ini dijelaskan dalam teori kategorisasi sosial. Teori kategorisasi sosial mengemukakan bahwa individu membagi dunia sosialnya menjadi dua kategori ekstrim yang saling terpisah. Selanjutnya faktor terakhir yang dapat menyebabkan timbulnya prasangka adalah faktor kognisi sosial. Prasangka juga dapat berkembang dari bagaimana cara individu berfikir mengenai individu lain. Gejala kognisi sosial yang berkontribusi bagi timbulnya prasangka adalah korelasi ilusif, yaitu adanya keseragaman dari kelompok luar (kelompok lain). Hal tersebut dikenal dengan istilah efek homogenitas kelompok luar (outgroup homogeneity effect).

\section{INTENSI MELAKUKAN DISKRIMINASI}

Menurut Chaplin (2006), intensi (intention) didefinisikan sebagai cara untuk mencapai suatu tujuan, ciri-ciri yang dapat dibedakan dari proses-proses psikologis, yang mencakup referensi atau kaitannya dengan suatu objek. Sedangkan menurut Ajzen (1988), intensi diasumsikan sebagai faktor motivasional yang 
mempengaruhi perilaku, yang mengindikasikan seberapa kuat keinginan seseorang untuk mencoba atau seberapa banyak usaha yang direncanakan untuk menampilkan perilaku. Ajzen dan Fishbein (dalam Hagger \& Nikos, 2005) memiliki hipotesis bahwa intensi mengindikasikan derajat pe-rencanaan seseorang terhadap perilaku mendatang dan menggambarkan sebe-rapa keras seseorang berkehendak untuk mencoba serta seberapa besar usaha yang dikeluarkan untuk melakukan suatu perilaku. Dengan kata lain, sebuah intensi menggambarkan derajat peren-canaan seseorang untuk melakukan sebuah perilaku dan seberapa besar usaha untuk mencoba melakukannya. Dari pengertian tersebut dapat di-simpulkan bahwa intensi merupakan probabilitas seseorang untuk melakukan sebuah perilaku tertentu.

Teerdapat dua teori intensi, yaitu Theory of Reasoned Action dan Theory of Planned Behavior. Menurut Theory of Reasoned Action, tingkah laku ditampilkan dengan alasan tertentu, de-ngan mempertimbangkan akibat dari tingkah laku tersebut, hasil akhir yang i-ngin dicapai, dan menghindari hal-hal yang tidak diinginkan. Dasar theory of reasoned action ini adalah adanya anggapan bahwa manusia selalu bertindak dengan cara yang masuk akal. Berdasarkan teori ini, intensi ditentukan oleh dua faktor utama, yaitu faktor yang berasal dari kepribadian orang yang bersangkutan dan faktor yang berasal dari pengaruh-pengaruh lingkungan sosialnya. Theory of planned behavior berasumsi bahwa individu melakukan aljabar kognitif, menimbang kekuatan dan nilai keyakinan yang dimiliki yang pada akhirnya mempengaruhi niat untuk bertindak (Mercer dan Debbie, 2012). Ada tiga aspek yang mempengaruhi intensi seseorang yaitu faktor sikap terhadap perilaku (attitude toward behavior), norma subjektif (subjective norm), dan persepsi atas kontrol perilaku (perceived behavioral control).

Diskriminasi adalah perilaku negatif yang ditujukan kepada orang lain. Menurut Myers (2012), diskriminasi adalah perilaku yang tidak pada tempatnya kepada satu kelompok dan anggota kelompoknya. Perilaku diskriminasi terkadang bersumber dari sikap yang penuh prasangka. Sementara Taylor dkk. (2012), mendeskripsikan diskriminasi sebagai sebuah perilaku negatif terhadap individu karena individu itu adalah anggota dari kelompok tertentu. Sarwono dan Eko (2009) menjelaskan diskriminasi sebagai perilaku negatif terhadap orang lain yang menjadi target prasangka. Diskriminasi merupakan tingkah laku di mana individu atau kelompok memperlakukan orang secara berbeda karena keanggotaan orang itu. Diskriminasi dapat beraneka ragam bentuknya, seperti perilaku mengabaikan, menggunakan bahasa yang tidak dipahami kelompok tertentu saat berkomunikasi, berbuat kasar, berbuat tidak adil, menjelek-jelekkan, mengancam, dan menyakiti. Jika prasangka sosial merupakan komponen afektif dari antagonisme etnis, maka diskriminasi merupakan komponen behavioral dari antagonisme etnis. Dari konsep intensi dan diskriminasi di atas, peneliti menyimpulkan bahwa intensi melakukan diskriminasi adalah probabilitas seseorang untuk melakukan perilaku negatif terhadap individu atau kelompok lain.

\section{METODE}

Jenis penelitian ini adalah penelitian kuantitatif. Rancangan penelitian yang digunakan adalah deskriptif dan korelasional. Rancangan penelitian ini digunakan untuk mendeskripsikan dan mengungkap hubungan antara suatu variabel dengan variabel lainnya. Dalam penelitian ini terdapat dua variabel yaitu variabel independen $(\mathrm{X})$ dan variabel dependen (Y). Variabel independen dalam penelitian ini adalah prasangka sosial, sedangkan variabel dependennya adalah intensi melakukan diskriminasi. Adapun populasi penelitian ini adalah mahasiswa etnis Jawa di universitas negeri dan swasta di Kota Malang. Teknik pengambilan sampel yang digunakan adalah purposive sampling. Sampel penelitian diambil di dua universitas di Kota Malang yaitu Universitas Negeri Malang dan Universitas Tribhuwana Tunggadewi.

Instrumen yang digunakan ada dua yaitu pengembangan subtle and blatant prejudice scales yang dirancang oleh Pettigrew dan Meertens dan skala intensi melakukan diskriminasi yang disusun oleh peneliti. Subtle and blatant prejudice scales tersusun atas 33 butir aitem dan skala intensi melakukan diskriminasi tersusun atas 48 butir aitem. Teknik analisis 
yang digunakan untuk menguji hipotesis mengenai hubungan antara prasangka sosial dan intensi melakukan diskriminasi mahasiswa etnis Jawa terhadap mahasiswa yang berasal dari Nusa Tenggara Timur yaitu teknik korelasi pearson product moment de-ngan nilai $\mathrm{p}<0,05$.

\section{HASIL}

Analisis deskriptif prasangka sosial menunjukkan bahwa tingkat prasangka sosial mahasiswa etnis Jawa terhadap mahasiswa yang berasal dari Nusa Tenggara Timur yang berada pada kategori rendah sebanyak 6 orang $(17,1 \%)$, sedang 23 orang $(65,7 \%)$, dan tinggi 6 orang $(17,1 \%)$. Jadi prasangka sosial mahasiswa etnis Jawa terhadap mahasiswa yang berasal dari Nusa Tenggara Timur sebagian besar termasuk dalam kategori sedang. Sementara analisis deskriptif intensi melakukan diskriminasi menunjukkan bahwa tingkat intensi melakukan diskriminasi mahasiswa etnis Jawa terhadap mahasiswa yang berasal dari mahasiswa Nusa Tenggara Timur yang berada pada kategori rendah sebanyak 6 orang $(17,1 \%)$, sedang 25 orang $(71,4 \%)$, dan tinggi 4 orang $(11,4 \%)$. Jadi intensi melakukan diskriminasi mahasiswa etnis Jawa terhadap mahasiswa yang berasal dari Nusa Tenggara Timur sebagian besar termasuk dalam kategori sedang.

Dari uji korelasi prasangka sosial dan intensi melakukan diskriminasi diperoleh koefisien korelasi sebesar 0,636 dengan taraf signifikansi kurang dari 0,05 ( $\mathrm{p}<0,05)$. Hal ini menunjukkan bahwa ada hubungan yang positif dan signifikan antara prasangka sosial dan intensi melakukan diskriminasi mahasiswa etnis Jawa terhadap mahasiswa yang berasal dari Nusa Tenggara Timur.

\section{PEMBAHASAN}

\section{Prasangka Sosial}

Prasangka sosial dari 35 orang mahasiswa etnis Jawa terhadap mahasiswa yang berasal dari Nusa Tenggara sebagian besar termasuk dalam kategori sedang. Munculnya prasangka sosial mahasiswa etnis Jawa terhadap mahasiswa yang berasal dari Nusa Tenggara Timur dapat timbul karena adanya kategorisasi. Dengan kategorisasi seseorang membedakan dirinya dengan orang lain, kelompoknya dengan kelompok lain, serta etnisnya dengan etnis lain. Pada umumnya orang akan membagi dunianya menjadi dua kategori yang berbeda, yaitu kategori "kita" dan "mereka" (Hanurawan, 2010). Kategori ini bisa berdasarkan berbagai hal, seperti tempat tinggal, pekerjaan, pendidikan, warna kulit, garis keturuan, etnis, dan lainnya. Mahasiswa etnis Jawa akan melihat mahasiswa lain yang memiliki latar belakang etnis yang sama sebagai in-group.

Mahasiswa asal Nusa Tenggara Timur memiliki latar belakang etnis yang berbeda dengan mereka dikelompokkan sebagai outgroup atau kelompok luar. Dari perbedaan ini akan muncul efek melebih-lebihkan perbedaan antar kelompok, salah satu contohnya yaitu bagaimana mahasiswa etnis Jawa melebihlebihkan perbedaan budaya yang dimilikinya dengan budaya mahasiswa yang berasal dari Nusa Tenggara Timur. Mahasiswa etnis Jawa juga lebih mungkin memberikan penilaian yang lebih buruk kepada mahasiswa asal Nusa Tenggara Timur sebagai out-group. Hal tersebut sesuai dengan pendapat dari Taylor dkk. (2012) bahwa orang cenderung mengevaluasi atributatribut out-group lebih negatif daripada atribut in-group.

Namun, tingkat prasangka sosial mahasiswa etnis Jawa terhadap mahasiswa yang berasal dari Nusa Tenggara Timur masih berada pada kategori sedang. Hal ini dapat disebabkan oleh adanya beberapa hal. Yang pertama adalah adanya kontak langsung antara mahasiswa etnis Jawa dengan mahasiswa yang berasal dari Nusa Tenggara Timur. Intensitas kontak kedua kelompok tersebut terjadi setiap hari dalam berbagai kegiatan di perguruan tinggi, seperti kegiatan perkuliahan, organisasi kampus, dan kegiatan-kegiatan lainnya. Intensitas kontak yang tinggi antar kedua kelompok tersebut sangat mungkin meningkatkan pemahaman yang lebih mendalam mengenai kesamaan diantara mereka yang selama ini mungkin tidak pernah mereka sadari. Dengan menyadari bahwa sebenarnya terdapat kesamaan diantara mereka bukan tidak mungkin akan menimbulkan daya tarik pada kedua kelompok itu.

Intensitas kontak secara langsung yang tinggi dari kedua kelompok itu juga akan menyebabkan berkurangnya ilusi keseragaman out 
group (illusion of out group homogeneity). Mahasiswa etnis Jawa akan menyadari bahwa sebenarnya mahasiswa yang berasal dari Nusa Tenggara Timur itu tidaklah homogen seperti yang mereka anggap sebelumnya. Mereka menyadari bahwa mahasiswa asal Nusa Tenggara Timur juga berbeda-beda (heterogen) seperti mahasiswa-mahasiswa asal daerah lainnya. Dengan demikian, mereka akan melihat seorang mahasiswa asal Nusa Tenggara Timur sebagai individu yang memiliki karakteristik yang unik dan berbeda dengan mahasiswa asal Nusa Tenggara Timur yang lain. Sehingga jika di kemudian hari terdapat permasalahan (misal keributan) yang dilakukan oleh seorang mahasiswa asal Nusa Tenggara Timur, maka mahasiswa etnis Jawa dapat melihatnya sebagai kesalahan individu tersebut dan bukan karena semua mahasiswa Nusa Tenggara Timur suka melakukan keributan. Jadi kontak antar kelompok dapat membuat seseorang tidak menyamaratakan semua individu dalam outgroup.

Hal tersebut sesuai dengan teori hipotesis kontak antar kelompok. Hipotesis kontak antar kelompok merupakan sebuah ide dari Allport dalam mengurangi prasangka, stereotip dan diskriminasi. Allport (dalam Putra dan Ardiningtyas, 2012) menduga bahwa de-ngan membentuk sebuah kontak antar kelompok, maka prasangka dengan sendirinya akan berkurang. Hanurawan (2011) menjelaskan bahwa adanya kesempatan melakukan interaksi sosial secara intensif melalui berbagai cara dengan kelompok lain dengan latar belakang yang berbeda lambat laun akan menyebabkan seseorang dapat mengembangkan perspektif baru tentang kelompok lain dan mengembangkan sikap yang lebih positif tentang kelompok lain. Kontak menyebabkan orang atau suatu kelompok dapat lebih mengenal kelompok lain yang sebelumnya tidak dikenal sama sekali. Informasi dan memori negatif yang telah disimpan sebelumnya terkait kelompok yang menjadi target prasangka akan dibandingkan dengan informasi baru yang mereka dapatkan dari kontak secara langsung. Namun sebuah kontak yang dapat me-ngurangi prasangka sosial harus memenuhi empat kondisi, diantaranya status kelompok yang setara di dalam suatu situasi, pencapaian yang sama, kerja sama antar kelompok, dan dukungan dari yang berwenang.

Kondisi pertama yang harus ada dalam membentuk kontak antar kelompok adalah status kelompok yang setara. Mahasiswa etnis Jawa dan mahasiswa yang berasal dari Nusa Tenggara Timur memperoleh perlakuan yang sama di universitas tempat mereka belajar. Posisi mereka setara sebagai mahasiswa, selain itu perlakuan yang diberikan oleh dosen tentunya juga tidak berbeda. Kondisi kedua adalah pencapaian atau tujuan yang sama. Mahasiswa etnis Jawa dan mahasiswa yang berasal dari Nusa Tengara Timur memiliki tujuan yang sama yaitu sama-sama menuntut ilmu di universitas tempat mereka belajar. Kondisi yang ketiga adalah adanya kerja sama antar kelompok. Berbagai kegiatan di universitas tentu menuntut kedua kelompok tersebut untuk saling bekerjasama, salah satunya adalah pembentukan kelompok dalam kegiatan perkuliahan di kelas. Anggota kelompok yang dibentuk bisa jadi terdiri dari mahasiswa etnis Jawa dan mahasiswa asal Nusa Tenggara Timur yang kemudian saling bekerjasama untuk menyelesaikan suatu tugas. Kondisi terakhir yang harus ada yaitu dukungan aparatus hukum. Hukum di sini dapat bermakna aturan-aturan yang ada di universitas. Hukum yang ada di Universitas Negeri Malang maupun Universitas Tribhuwana Tunggadewi tidak hanya terfokus pada mahasiswa dari satu etnis saja, namun juga pada mahasiswa etnis lainnya. Terpenuhinya keempat kondisi tersebut menyebabkan kontak kedua kelompok tersebut berlangsung dengan baik.

\section{Intensi Melakukan Diskriminasi}

Intensi melakukan diskriminasi menunjukkan seberapa besar upaya mahasiswa etnis Jawa untuk mewujudkan rencana melakukan diskriminasi terhadap mahasiswa yang berasal dari Nusa Tenggara Timur. Intensi melakukan diskriminasi etnis Jawa yang berada pada kategori sedang juga dapat disebabkan oleh beberapa hal. Sebagaimana dalam teori perilaku berencana bahwa terdapat tiga determinan yang membentuk sebuah intensi. Yang pertama yaitu sikap terhadap perilaku. Tingkat intensi melakukan diskriminasi yang sedang bisa disebabkan oleh sikap mahasiswa etnis Jawa 
yang memandang bahwa melakukan diskriminasi merupakan perilaku yang negatif dan juga tidak ada manfaatnya bagi mereka. Dengan kata lain mahasiswa etnis Jawa memiliki sikap yang cenderung negatif terhadap perilaku diskriminasi. Determinan yang kedua yaitu norma subjektif. Kemungkinan kedua yang menyebabkan intensi melakukan diskriminasi berada pada kategori sedang adalah tidak adanya dorongan dari lingkungan di sekitarnya untuk melakukan tindakan tersebut, misalnya dorongan dari teman-teman sesama mahasiswa etnis Jawa. Mereka percaya bahwa lingkungannya tidak akan menyetujui keinginannya untuk melakukan diskriminasi terhadap mahasiswa yang berasal dari Nusa Tenggara Timur. Selanjutnya determinan yang terakhir yaitu adanya kontrol perilaku. Hal tersebut berkaitan dengan pengalaman masa lalu dan perkiraan seberapa sulit untuk melakukan perilaku yang bersangkutan. Kemungkinan ketiga penyebab intensitas melakukan diskriminasi berada pada kategori sedang yaitu mahasiswa etnis Jawa tersebut tidak pernah melakukan tindakan diskriminatif terhadap mahasiswa yang berasal dari Nusa Tenggara Timur. Selain itu mereka juga meyakini bahwa dirinya tidak memiliki kesempatan untuk menampilkan perilaku tersebut.

Sama halnya seperti pada prasangka sosial, adanya kontak langsung antara mahasiswa etnis Jawa dengan mahasiswa yang berasal Nusa Tenggara Timur akan membuat mereka saling mengenal satu sama lain. Setelah mereka mengenal dan mengetahui kesamaan apa saja yang mereka miliki akan timbul daya tarik dari kedua kelompok tersebut. Dengan berkurangnya perbedaan yang mereka rasakan, maka akan timbul perasaan suka dan tidak memunculkan intensi untuk melakukan diskriminasi. Pada akhirnya, kontak langsung dengan intensitas yang tinggi akan menyebabkan mereka melihat diri mereka sebagai sebuah kelompok yang lebih besar, yaitu sebagai mahasiswa yang berasal dari sebuah universitas yang sama.

Beberapa penelitian lanjut me-ngenai hipotesis kontak mendukung pendapat Allport bahwa kontak secara langsung dengan kelompok lain dapat mengurangi diskriminasi. Hasil penelitian Wilder dan Thompson (dalam Putra dan Ardiningtyas, 2012) menunjukkan bahwa interaksi antar kelompok secara intens berpotensi mengurangi bias pe-ngetahuan mengenai kelompok lain. Penelitian yang dilakukan oleh Parsudi (dalam Putra dan Ardiningtyas, 2012) di Indonesia mengenai perlakuan diskriminatif pembina transmigrasi kepada para transmigran menunjukkan hasil yang serupa. Hasil penelitian tersebut menunjukkan bahwa pembina transmigrasi yang memiliki tingkat kontak sosial tinggi cenderung untuk tidak memberikan perlakuan yang diskriminatif. Jadi, adanya kontak atau interaksi yang intens antara mahasiswa etnis Jawa dan mahasiswa yang berasal dari Nusa Tenggara Timur menyebabkan intensi mahasiswa etnis Jawa untuk melakukan diskriminasi terhadap mahasiswa yang berasal dari Nusa Tenggara Timur masih berada dalam kategori sedang.

\section{Hubungan antara Prasangka Sosial dan In- tensi Melakukan Diskriminasi}

Hasil uji hipotesis menunjukkan bahwa ada hubungan yang positif dan signifikan antara prasangka sosial dan intensi melakukan diskriminasi mahasiswa etnis Jawa terhadap mahasiswa yang berasal dari Nusa Tenggara Timur. Hubungan antara kedua variabel tersebut terlihat pada tingkat prasangka sosial yang sedang berhubungan dengan intensi melakukan diskriminasi yang sedang. Berdasarkan hasil analisis de-ngan formula pearson product moment terhadap data prasangka sosial dan intensi melakukan diskriminasi mahasiswa etnis Jawa terhadap mahasiswa yang berasal dari Nusa Tenggara Timur diperoleh $\mathrm{p}$ value $0,000<0,05$ dengan $r$ sebesar 0,608 . Hal ini berarti bahwa prasangka sosial mahasiswa etnis Jawa terhadap mahasiswa yang berasal dari Nusa Tenggara Timur dapat digunakan sebagai sebuah prediktor dalam me-ngungkap intensi melakukan diskriminasi terhadap mahasiswa yang berasal dari Nusa Tenggara Timur. Hal ini sejalan dengan penjelasan oleh Hanurawan (2010) bahwa sikap mempengaruhi perilaku melalui variabel perantara yang disebut dengan niat (intensi) untuk melaksanakan perilaku. Sebagai sebuah sikap, prasangka sosial dapat digunakan untuk memprediksi perilaku diskriminasi melalui perantara dari intensi melakukan diskriminasi. 
Beberapa penelitian sebelumnya banyak mengaitkan hubungan prasangka sosial dan diskriminasi. Seperti yang diungkapkan oleh Myers (2012) bahwa perilaku yang mendiskriminasi terkadang bersumber dari sikap penuh prasangka. Sebagai wujud dari perilaku, diskriminasi juga erat kaitannya dengan intensi. Hal ini berdasarkan bahwa sebuah perilaku individu seringkali didahului oleh adanya intensi melakukan perilaku itu. Fishbein dan Ajzen (dalam Sarwono, 2002) juga menjelaskan bahwa dengan mengukur sikap terhadap intensi sama dengan mengukur perilaku itu sendiri, karena menurut mereka terdapat hubungan yang dekat antara intensi dan perilaku. Hal ini bermakna bahwa mengukur hubungan antara prasangka sosial dan intensi melakukan diskriminasi sama halnya dengan me-ngukur hubungan antara prasangka sosial dan diskriminasi.

Penelitian mengenai prasangka dan diskriminasi ini banyak sekali jumlahnya. Dovidio dkk. (dalam Whitley dan Mary, 2010) meringkas hasil dari 23 penelitian mengenai hubungan prasangka dan diskriminasi. Rata-rata koefisien korelasi dari penelitian-penelitian tersebut adalah $0,32(\mathrm{r}=0,32)$. Selain itu, sebuah metaanalisis dari 60 penelitian lainnya menemukan hasil yang serupa dengan nilai $r=0,36$. Hubungan yang lebih kuat juga ditemukan antara prasangka dan intensi melakukan diskriminasi, di mana koefisien korelasi keduanya sebesar $0,45(\mathrm{r}=0,45)$. Hal ini menunjukkan bahwa hubungan antara prasangka seseorang dan ucapan seseorang mengenai apa yang akan dilakukannya lebih kuat daripada hubungan antara prasangka dan apa yang mereka lakukan sebenarnya. Penelitian lain mengenai hubungan antara prasangka dan intensi melakukan diskriminasi juga dilakukan di Jerman. Penelitian tersebut dilakukan untuk mengungkap hubungan prasangka dan intensi melakukan diskriminasi masyarakat Jerman terhadap berbagai kelompok minoritas yang ada disana seperti homoseksual, tu-nawisma, penyandang disabilitas, wanita, yahudi, orang asing, dan muslim. Data diperoleh melalui survei telepon dengan jumlah sampel $1.778 \quad(\mathrm{~N}=1.778)$. Intensi melakukan diskriminasi terhadap yahudi dan homoseksual memiliki kaitan erat dengan beberapa aspek prasangka dibandingkan pada kelompok-kelompok lain. Range koefisien korelasi prasangka dan intensi melakukan diskriminasi terhadap yahudi sebesar 0,26 sampai 0,45 . Sementara itu, range koefisien korelasi prasangka dan intensi melakukan diskriminasi pada homoseksual sebesar 0,19 sampai 0,53 (Asbrock dkk., 2007).

Penelitian mengenai hubungan antara prasangka sosial dan intensi melakukan diskriminasi etnis Jawa terhadap mahasiswa yang berasal dari Nusa Tenggara Timur ini masih memiliki kekurangan. Keterbatasan jumlah sampel penelitian membuat penelitian ini tidak dapat digeneralisasi kepada populasi penelitian. Hal ini menyebabkan hasil penelitian hanya digunakan untuk me-ngambil kesimpulan pada 35 orang mahasiswa yang menjadi sampel penelitian saja. Penelitian serupa mengenai hubungan prasangka dan intensi melakukan diskriminasi di Jerman tentu hasilnya akan dapat mewakili populasi karena jumlah sampel yang besar yaitu 1.778 orang.

\section{KESIMPULAN}

Berdasarkan hasil analisis data dan pembahasan yang telah diuraikan sebelumnya dapat disimpulkan bahwa prasangka sosial mahasiswa etnis Jawa terhadap mahasiswa yang berasal dari Nusa Tenggara Timur sebagian besar termasuk dalam kategori sedang. Sedangkan intensi melakukan diskriminasi mahasiswa etnis Jawa terhadap mahasiswa yang berasal dari Nusa Tenggara Timur sebagian besar juga termasuk dalam kategori sedang. Hasil penelitian ini menunjukkan bahwa ada hubungan positif dan signifikan antara prasangka sosial dan intensi melakukan diskriminasi mahasiswa etnis Jawa terhadap mahasiswa yang berasal dari Nusa Tenggara Timur.

\section{SARAN}

Berdasarkan hasil penelitian yang diperoleh, maka dapat dikemukakan beberapa saran bagi masyarakat, pemerintah daerah, perguruan tinggi, dan peneliti selanjutnya. Masyarakat yang berada di lingkungan yang terdapat mahasiswa yang berasal dari Nusa Tenggara Timur juga perlu meningkatkan interaksi yang lebih intens dengan mereka. Pemerintah perlu membuat suatu program sebagai usaha untuk meningkatkan kondisi ini, 
yaitu bagaimana membuat tingkat prasangka sosial dan intensi melakukan diskriminasi mahasiswa etnis Jawa terhadap mahasiswa yang berasal dari Nusa Tenggara Timur dapat menjadi lebih rendah lagi. Pihak perguruan tinggi dapat melakukan upaya-upaya untuk membuat mahasiswa etnis Jawa dan mahasiswa yang berasal dari Nusa Tenggara Timur lebih mengenal satu sama lain sejak kegiatan PKPT (Pengenalan Kegiatan Perguruan Tinggi). Peneliti selanjutnya diharapkan dapat menambah jumlah sampel penelitian sehingga hasil penelitian dapat digeneralisasi pada populasi. Selain itu peneliti selanjutnya juga dapat mengembangkan ruang lingkup penelitian sehingga subjek penelitian tidak hanya terbatas pada mahasiswa saja, namun juga masyarakat yang mengetahui mahasiswa asal Nusa Tenggara Timur.

\section{DAFTAR RUJUKAN}

Ahmadi, Abu. 2007. Psikologi Sosial. Jakarta: PT Rineka Cipta.

Ajzen, Icek. 1988. Attitudes, Personality, and Behavior. Milton Keyness: Open University Press.

Asbrock, F., Oliver, C., dan Ulrich, W. 2007. The Road to Negative Behavior: Discriminatory Intentions in the German Population. International Journal of Conflict and Violence, (Online), Vol. 1 (1) 2007, pp. 4-18, (www.ijcv. org diakses 30 April 2016).

Brown, Rupert. 2005. Prejudice: Menangani Prasangka dari Perspektif Psikologi Sosial. Yogyakarta: Pustaka Pelajar.

Chaplin, J.P. 2006. Kamus Lengkap Psikologi. Diterjemahkan oleh: Kartini Kartono. Jakarta: Raja Grafindo Persada.

De Caroli, M. E., Rosella, F., dan Elisabetta, S. 2012. Subtle and Blatant Prejudice toward Chinese People in Italian Adolescents and Young Adult: The Role of "Friendship" and "Outgroup Representation" Procedia Social and Behavioral Science, (Online),(http://www.sciencedirect.co $\underline{\mathrm{m}}$, diakses 15 November 2015).

Hagger, Martin dan Nikos, Chatzisarantis. 2005. The Social Psychology of Exercise and
Sport. Berkshire: Open University Press.

Hanurawan, Fattah. 2010. Psikologi Sosial Suatu Pengantar. Bandung: PT Remaja Rosdakarya Offset.

Hanurawan, Fattah. 2011. Psikologi Sosial Terapan dan Masalah-Masalah Perilaku Sosial. Malang: Fakultas Ilmu Pendidikan Universitas Negeri Malang.

Mercer, Jenny dan Debbie, Clayton. 2012. Psikologi Sosial. Jakarta: Erlangga.

Myers, David G. 2012. Psikologi Sosial Edisi 10.Jakarta: Salemba Humanika.

Na'im dan Syaputra. 2011. Kewarganegaraan, Suku, Bangsa, Agama, dan Bahasa Sehari-hari Penduduk Indonesia: Hasil Sensus Penduduk 2010. Jakarta: Badan Pusat Statistik

Putra, Idhamsyah Eka dan Ardiningtyas, Pitaloka. 2012. Psikologi Prasangka: Sebab, Dampak, dan Solusi. Bogor: Ghalia Indonesia.

Sarwono, Sarlito Wirawan. 2002. Psikologi Sosial: Individu dan Teori-Teori Psikologi Sosial. Jakarta: Balai Pustaka.

Sarwono, Sarlito W. dan Eko, A. Meinarno. 2009. Psikologi Sosial. Jakarta: Salemba Humanika.

Taylor, Shelley E., Letitia, Anne Peplau, dan David, O. Sears. 2012. Psikologi Sosial Edisi KeduaBelas. Jakarta: Kencana Prenada.

Terasntt.com. 2 Maret. 2016. Berpotensi Konflik dengan Masyarakat Malang: Mahasiswa Asal NTT Temui Wawali, (Online), (www. terasntt.com/ berpotensi-konflik-dengan-masyarakatmalang-n-mahasiswa-asal-ntt-temuiwawali/ diakses 19 Mei 2016).

Whitley, Bernard E. Jr dan Mary, E. Kite. 2010. The Psychology of Prejudice and Discrimination, Second Edition. Canada: Nelson Education Ltd. 